\author{
Zygmunt Giziński \\ Marcin Gqsiewski \\ Pawel Giziński \\ Marcin Żulawnik \\ Instytut Elektrotechniki, Zakład Trakcji Elektrycznej
}

\title{
Zasobnikowe układy zasilania w pojazdach trakcyjnych
}

\begin{abstract}
W niniejszym artykule znajduja się wyniki badań uktadu zasobnika kondensatorowego przeprowadzone przez Zakład Trakcji Elektrycznej Instytutu Elektrotechniki $w$ Warszawie. Superkondensator wraz z systemem sterowania zostat zaprojektowany, wykonany $i$ zabudowany na trzech pojazdach trakcyjnych: trolejbusie Jelcz PR110 z napędem asynchronicznym $w$ Lublinie, trolejbusie Jelcz M121E z napędem prądu stałego w Kownie oraz w tramwaju $116 N$ również z napędem pradu stałego, który jest eksploatowany w Warszawie. $W$ każdym $z$ tych trzech przypadków została potwierdzona celowość zastosowania zasobnika.
\end{abstract}

\section{Wstęp}

Rozwój technologii produkcji kondensatorów dużej pojemności doprowadził do opracowania ogniw $3000 \mathrm{~F}$ przy napięciu $2,5 \div 2,7 \mathrm{~V}$.

$\mathrm{Z}$ takich ogniw budowane są moduły na napięcie $54 \div 390$ V o pojemności $150 \mathrm{~F} \div 18 \mathrm{~F}$.

Łączenie szeregowe takich modułów przy zastosowaniu zabezpieczeń napięciowych zapobiegających przekroczeniu maksymalnej wartości napięcia ogniw ok. 2,8V umożliwia wykonanie zasobników energii na napięcie $750 \div 780 \mathrm{~V}$ dla pojazdów komunikacji miejskiej. ok $2 \mathrm{MJ}$.

Energia użyteczna takich zasobników wynosi

Możliwość wykorzystywania pełnej wartości energii użytecznej zasobnika podczas rozruchu i hamowania pojazdu jest zależne od sposobu dystrybucji tej energii podczas jazdy pojazdu.

Wykorzystanie całej energii użytecznej zasobnika kondensatorowego możliwe jest w systemie regulacyjnym opracowanym i wdrożonym przez Instytut Elektrotechniki (Patent).

Instytut Elektrotechniki prowadzi prace nad zastosowaniem kondensatorowych zasobników energii od ponad 5 lat. Prace te doprowadziły do opracowania i wdrożenia zasobnikowych układów dla następujących pojazdów:

- układ dla trolejbusu Jelcz PR110 z napędem falownikowym AC-165kW i zasobnikiem 8,9F - 780V dla MPK Lublin - 2007r.

- układ dla trolejbusu Jelcz M121E z napędem silnikiem DC120kW i zasobnikiem 8,9F $780 \mathrm{~V}$ dla Autrolis w Kownie - 2008r.

- układ dla tramwaju $116 \mathrm{~N} \mathrm{z}$ napędem DC $4 \times 50 \mathrm{~kW}$ z zasobnikiem $10 \mathrm{~F}-760 \mathrm{~V}$ dla Tramwajów Warszawskich - 2009r.
- kontenerowy zasobnik sieciowy $8,9 \mathrm{~F}-780 \mathrm{~V}$ dla tramwajowej linii wybiegowej Tramwajów Elbląskich w Elblagg - 2010r.

- podstacyjny zasobnik $10 \mathrm{~F}-760 \mathrm{~V}$ dla sieci trolejbusowej PKT Gdynia - 2011r.

\section{Kondensatorowe zasobniki energii}

Najbardziej popularne zasobniki - baterie elektrochemiczne (akumulatory) przy dobrych parametrach energetycznych niestety mają szereg wad np.: duża masa, stosunkowo niska wydajność prądowa, krótka żywotność. Jednym z ostatnich osiagnnięć dających możliwości do gromadzenia energii jest superkondensator. Łączy on w sobie cechy akumulatorów oraz zwykłych kondensatorów, a swoje zalety zawdzięcza bardzo dużej pojemności, nawet kilku tysięcy faradów! Napięcie maksymalne pojedynczego kondensatora nie przekracza $2,7 \mathrm{~V}$ i dlatego trzeba je łączyć w stosy szeregowe.

Firmy, które zajmują się produkcją superkondensatorów oferują gotowe moduły połączonych szeregowo ogniw z wyrównywaniem napięć na poszczególnych celkach, co umożliwia wykorzystanie zasobnika jako gotowego podzespołu.

Superkondensatory produkowane sa obecnie przez szereg firm i dostarczane $\mathrm{w}$ blokach modułowych:

$\begin{array}{llll}\text { - } & \text { Maxwell } & 390 \mathrm{~V} & -17,8 \mathrm{~F} \\ \text { - } & \text { Batscap } & 54 \mathrm{~V} & -150 \mathrm{~F} \\ \text { - } & \text { LS Mtron } & 190 \mathrm{~V} & -41,7 \mathrm{~F}\end{array}$

$\mathrm{Z}$ modułów takich budowane kondensatorowe zasobniki energii dla pojazdów komunikacji miejskiej. 


\begin{tabular}{|c|c|c|c|}
\hline Parametry & $\begin{array}{c}\text { MAXWELL } \\
\text { 2x HTM390 }\end{array}$ & $\begin{array}{c}\text { BATSCAP } \\
\text { 14x M54V150F }\end{array}$ & $\begin{array}{c}\text { LS MTRON } \\
4 \mathrm{x} \text { LS 190V/41.7F }\end{array}$ \\
\hline Znamionowe napięcie pracy & $780 \mathrm{~V}$ & $756 \mathrm{~V}$ & $760 \mathrm{~V}$ \\
\hline Znamionowa pojemność & $8.9 \mathrm{~F}$ & $10.7 \mathrm{~F}$ & $10.4 \mathrm{~F}$ \\
\hline Oporność szeregowa DC & $\sim 130 \mathrm{~m} \Omega$ & $\sim 56 \mathrm{~m} \Omega$ & $\sim 115 \mathrm{~m} \Omega$ \\
\hline Energia zasobnika & $752 \mathrm{Wh}$ & $849 \mathrm{Wh}$ & $834 \mathrm{Wh}$ \\
\hline $\begin{array}{c}\text { Dostępna energia } \\
\text { (Uzn } \div 1 / 2 \text { Uzn) }\end{array}$ & $564 \mathrm{Wh}$ & $634 \mathrm{Wh}$ & $625 \mathrm{Wh}$ \\
\hline Emax. odniesiona do masy & $2.28 \mathrm{Wh} / \mathrm{kg}$ & $3.57 \mathrm{Wh} / \mathrm{kg}$ & $2.00 \mathrm{Wh} / \mathrm{kg}$ \\
\hline Żywotność & $>1000000 \mathrm{cykli}$ & $>1000000 \mathrm{cykli}$ & $>1000000 \mathrm{cykli}$ \\
\hline Min. temperatura pracy & $-40^{\circ} \mathrm{C}$ & $-30^{\circ} \mathrm{C}$ & $-40^{\circ} \mathrm{C}$ \\
\hline Max. temperatura pracy & $+65^{\circ} \mathrm{C}$ & $+60^{\circ} \mathrm{C}$ & $+65^{\circ} \mathrm{C}$ \\
\hline Stopień IP & $\mathrm{IP} 65$ & $\mathrm{IP} 65$ & $\mathrm{IP} 65$ \\
\hline Masa & $\sim 330 \mathrm{~kg}$ & $\sim 238$ & $\sim 416 \mathrm{~kg}$ \\
\hline
\end{tabular}

Parametry katalogowe modułów kondensatorowych LS Mtron

Tab. 2

\begin{tabular}{|c|c|}
\hline Parametry & LS $190 \mathrm{~V} / 41.7 \mathrm{~F}$ \\
\hline Maksymalne napięcie pracy & $190 \mathrm{~V}$ \\
\hline Znamionowa pojemność & $41.7 \mathrm{~F}$ \\
\hline Tolerancja pojemności & b.d. \\
\hline Oporność szeregowa DC & $28.8 \mathrm{~m} \Omega$ \\
\hline Oporność szeregowa $100 \mathrm{~Hz}$ & b.d. \\
\hline $\begin{array}{l}\text { Dostępna energia od Uzn do } 1 / 2 \\
\text { Uzn }\end{array}$ & $156.81 \mathrm{Wh}$ \\
\hline $\begin{array}{c}\text { Energia max. odniesiona do } \\
\text { masy }\end{array}$ & $2.01 \mathrm{Wh} / \mathrm{kg}$ \\
\hline $\begin{array}{l}\text { Energia max. odniesiona do } \\
\text { objętości }\end{array}$ & $2.11 \mathrm{Wh} / 1$ \\
\hline Maksymalny prąd ciągły & $150 \mathrm{~A}$ \\
\hline Maksymalny prąd & 400A ( 10 sec. $)$ \\
\hline Żywotność & $>1000000$ cykli \\
\hline Napięcie izolacji AC & $5250 \mathrm{~V}$ \\
\hline Minimalna temperatura pracy & $-40^{\circ} \mathrm{C}$ \\
\hline Maksymalna temperatura pracy & $+65^{\circ} \mathrm{C}$ \\
\hline Stopień IP & IP65 \\
\hline Masa & $104 \mathrm{~kg}$ \\
\hline $\begin{array}{c}\text { Wymiary (długość / szerokość / } \\
\text { wysokość) }\end{array}$ & $918 / 453 / 238 \mathrm{~mm}$ \\
\hline
\end{tabular}

W trolejbusach zastosowaliśmy po dwie szeregowo połączone baterie firmy Maxwell 390V $17,8 \mathrm{~F}$ a w tramwaju $116 \mathrm{~N} 4$ szeregowo połączone baterie f-my LS Mtron 190V - 41,7F.

\section{Energia rekuperacji pojazdów}

Głównym kryterium doboru energii użytecznej zasobnika kondensatorowego jest akumulacja energii kinetycznej pojazdu podczas hamowania. Dla warunków komunikacji miejskiej można przyjać kryterium akumulacji energii przy hamowaniu $\mathrm{Z}$ prędkości $50 \mathrm{~km} / \mathrm{h}$ pojazdu średnio zapełnionego.

Podczas hamowania w tramwajach wieloczłonowych o masie $30 \div 40 \mathrm{Mg}$ osie toczne hamowane są za pomocą hamulców mechanicznych pochłaniających od $0,2 \div 0,3$ energii kinetycznej tramwaju.

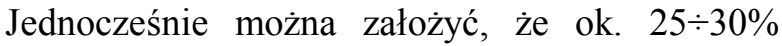
energii hamowania mogą odebrać inne pojazdy znajdujące się na tym samym odcinku zasilania. Możliwa do rekuperacji energia pomniejszona jest o opory ruchu i sprawność układu przetwarzania. Sumaryczną sprawność można określić na ok. $0,80 \div 0,85$.

Zasobnik kondensatorowy powinien być dobrany zgodnie z normami na maksymalną wartość napięcia sieci trakcyjnej - 720V i minimalną wartość - 400V. Energia zasobnika wynosi więc ok. $180 \mathrm{~kJ} / 1 \mathrm{~F}$, czyli ok. $0,07 \mathrm{kWh} / 1 \mathrm{~F}$. 


\begin{tabular}{|c|c|c|c|c|c|c|}
\hline $1 . p$. & Pojazd & $\begin{array}{c}\text { Masa } \\
\text { własna } \\
{[\mathrm{Mg}]}\end{array}$ & $\begin{array}{c}\text { Obciązenie } \\
{[\mathrm{Mg}]}\end{array}$ & $\begin{array}{c}\text { Energia } \\
\text { kinetyczna } \\
{[\mathrm{kWh}]}\end{array}$ & $\begin{array}{c}\text { Energia } \\
\text { rekuper. } \\
{[\mathrm{kWh}]}\end{array}$ & $\begin{array}{c}\text { Pojemność } \\
\text { "C" } \\
{[\mathrm{F}]}\end{array}$ \\
\hline 1 & Trolejbus & 12 & 6 & 0,43 & 0,36 & 5,2 \\
\hline 2 & $\begin{array}{c}\text { Tramwaj } \\
\text { czteroosiowy }\end{array}$ & 17 & 10 & 0,72 & 0,61 & 8,7 \\
\hline 3 & $\begin{array}{c}\text { Tramwaj } \\
\text { trójczłonowy }\end{array}$ & 30 & 15 & 1,2 & 1,00 & 14,3 \\
\hline 4 & $\begin{array}{c}\text { Tramwaj } \\
\text { trójczłonowy 0,75 } \\
\text { Tramwaj } \\
\text { pięcioczłonowy }\end{array}$ & 30 & 15 & 0,8 & 0,68 & 10,0 \\
\hline $4 \mathrm{a}^{*}$ & $\begin{array}{c}\text { Tramwaj } \\
\text { pięcioczłonowy 0,75 }\end{array}$ & 40 & 18 & 1,55 & 1,32 & 19,0 \\
\hline
\end{tabular}

* 25\% energii zwrócona jest do sieci trakcyjnej lub tracona w hamulcach mechanicznych

Przedstawione w tabeli 3 wartości niezbędnej pojemności zasobnika powinny być skorygowane koniecznością zmniejszenia maksymalnej wartości prądu pobieranego z sieci trakcyjnej podczas rozruchu a także maksymalną wartością prądu obciążenia kondensatorów ciagła i krótkotrwała.

\section{Układ regulacyjny pojazdu $z$ kondensa- torowym zasobnikiem energii}

Schemat ideowy układu elektrycznego pojazdu napędzanego silnikami prądu stałego lub asynchronicznymi z kondensatorowym zasobnikiem energii oraz przekształtnikami regulującymi dystrybucję energii zasobników pokazana jest na rys 1

\section{Działanie układu regulacyjnego}

Dla wykorzystania pełnej energii użytecznej zasobnika odpowiadającej różnicy energii kondensatorów dla maksymalnego napięcia Un i minimalnej dla napięcia 0,5 Un zastosowano specjalny system dystrybucji energii zasobnika (Patent IEL).

System ten uwzględnia prędkość pojazdu zmienną wartość napięcia sieci trakcyjnej, maksymalną żądaną wartość prądu sieci trakcyjnej, maksymalną dopuszczalną krótkotrwale wartość prądu kondensatorów, a także wymaganą dla pojazdów trakcyjnych maksymalną wartość momentu hamującego silników podczas hamowania $\mathrm{z}$ dużych prędkości.

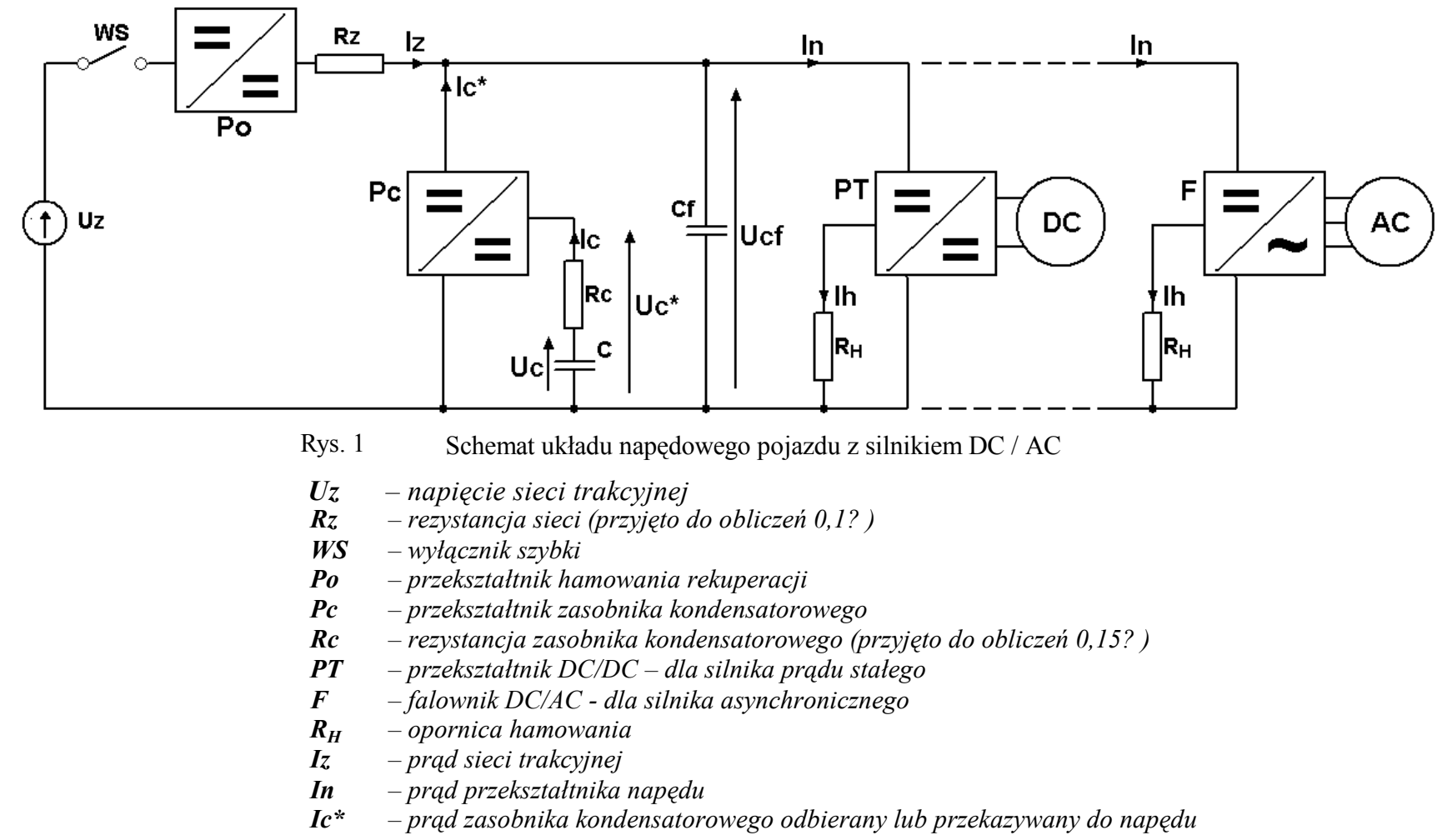




\section{Rozruch pojazdu}

Przekształtniki PT lub F regulują wartość prądu silników. Prąd pobierany przez napęd narasta liniowo osiagając wartość maksymalną równą sumie prądów rozruchu silników przy prędkości znamionowej pojazdu.

Przekształtnik PC reguluje wartość prądu Ic* dostarczonego do napędu wspomagając sieć trakcyjna. Dla $\mathrm{Uc}<\mathrm{Uz}$ przekształtnik $\mathrm{PC}$ podwyższa wartość napięcia dostarczanego do napędu aż do rozładowania kondensatorów do Ucmin. Ograniczając maksymalną wartość prądu pobieranego z sieci trakcyjnej.

Przykładowy przebieg takiej regulacji dla trolejbusu z napędem silnikami DC $-120 \mathrm{KW}$ pokazany jest na rys 2 .

dla rozruchu do prędkości $\mathrm{V}=60 \mathrm{~km} / \mathrm{h}$ otrzymujemy: droga rozruchu pojazdu $\mathrm{Lr}=200 \mathrm{~m}$ energia pobrana $\mathrm{z}$ zasobnika energia pobrana $z$ sieci zasilającej energia pobrana do napędu Ecr $=1540 \mathrm{kWs}$ $\mathrm{Ezr}=1425 \mathrm{kWs}$ $\mathrm{Enr}=2872 \mathrm{kWs}$

dla hamowania z prędkości $\mathrm{V}=55 \mathrm{~km} / \mathrm{h}$ otrzymujemy: droga hamowania pojazdu $\quad \mathrm{Lh}=117 \mathrm{~m}$ energia zgromadzona $\mathrm{w}$ zasobniku $\quad \mathrm{Ech}=1540 \mathrm{kWs}$ energia pobrana $\mathrm{z}$ napędu $\quad \mathrm{Enh}=1664 \mathrm{kWs}$ energia oddana do sieci zasilającej $\quad E z h=49 \mathrm{kWs}$ energia stracona $\mathrm{w} \mathrm{R}_{\mathrm{H}}$

$\mathrm{Ehh}=0 \mathrm{kWs}$

Energia pobrana przez napęd wynosi ok $2900 \mathrm{kWs}$ Energia pobrana z zasobnika wynosi ok $1570 \mathrm{kWs}$ Energia pobrana z sieci trakcyjnej wynosi ok $1450 \mathrm{kWs}$

\section{Hamowanie}

Podczas hamowania dla uzyskania dużej wartości momentu silników napięcie filtru wejściowego $U_{\mathrm{CF}}$ otrzymywane jest na poziomie wyższym niż wartość napięcia sieci trakcyjnej $\mathrm{U}_{\mathrm{CF}}=700 \div 750 \mathrm{~V}$. Wartość prądu zwracanego do sieci trakcyjnej i zasobnika kondensatorowego regulowane są przekształtnikami PO i PC.

Zastosowany system regulacyjny ma za zadanie dostarczenie do zasobnika energii zapewniające naładowanie kondensatorów do maksymalnej dopuszczalnej wartości napięcia.

Przykładowy przebieg hamowania trolejbusu z prędkości $55 \mathrm{~km} / \mathrm{h}$ pokazane są na rys 2 .

Energia zwrócona przez napęd wynosi ok $1700 \mathrm{kWs}$ Energia zgromadzona $\mathrm{w}$ zasobniku wynosi ok $1570 \mathrm{kWs}$

Energia zwrócona do sieci trakcyjnej wynosi ok $12 \mathrm{kWs}$

Rys. 2 Rozruch i hamowanie trolejbusu

(silnik DC, To - sterowany, $\mathrm{m}=10+6 \mathrm{Mg}, \mathrm{L}=520 \mathrm{~m}, \mathrm{C}=8 \mathrm{~F}, \mathrm{Uz}=650 \mathrm{~V}$, $\mathrm{Uc}_{\mathrm{o}}=740 \mathrm{~V}, \mathrm{Ir}_{\max }=320 \mathrm{~A}, \mathrm{Ih}_{\max }=250 \mathrm{~A}$ )

\begin{tabular}{|c|c|}
\hline \multicolumn{2}{|l|}{ Oznaczenia: } \\
\hline $\mathbf{U z}$ & - napięcie sieci trakcyjnej \\
\hline Uef & - napięcie kondensatora filtru \\
\hline $\mathrm{Uc}$ & - napięcie kondensatora zasobnika \\
\hline Uc* & - napięcie zasobnika \\
\hline $\mathbf{I z}$ & - prąd sieci trakcyjnej \\
\hline In & - prad zespołu napęlowego \\
\hline Ic* & - prąd przekształtnika zasobnika \\
\hline Ih & - prąd rezystora hamowania \\
\hline $\mathbf{L}$ & - droga pojazdu \\
\hline V & - prędkość pojazdu \\
\hline
\end{tabular}

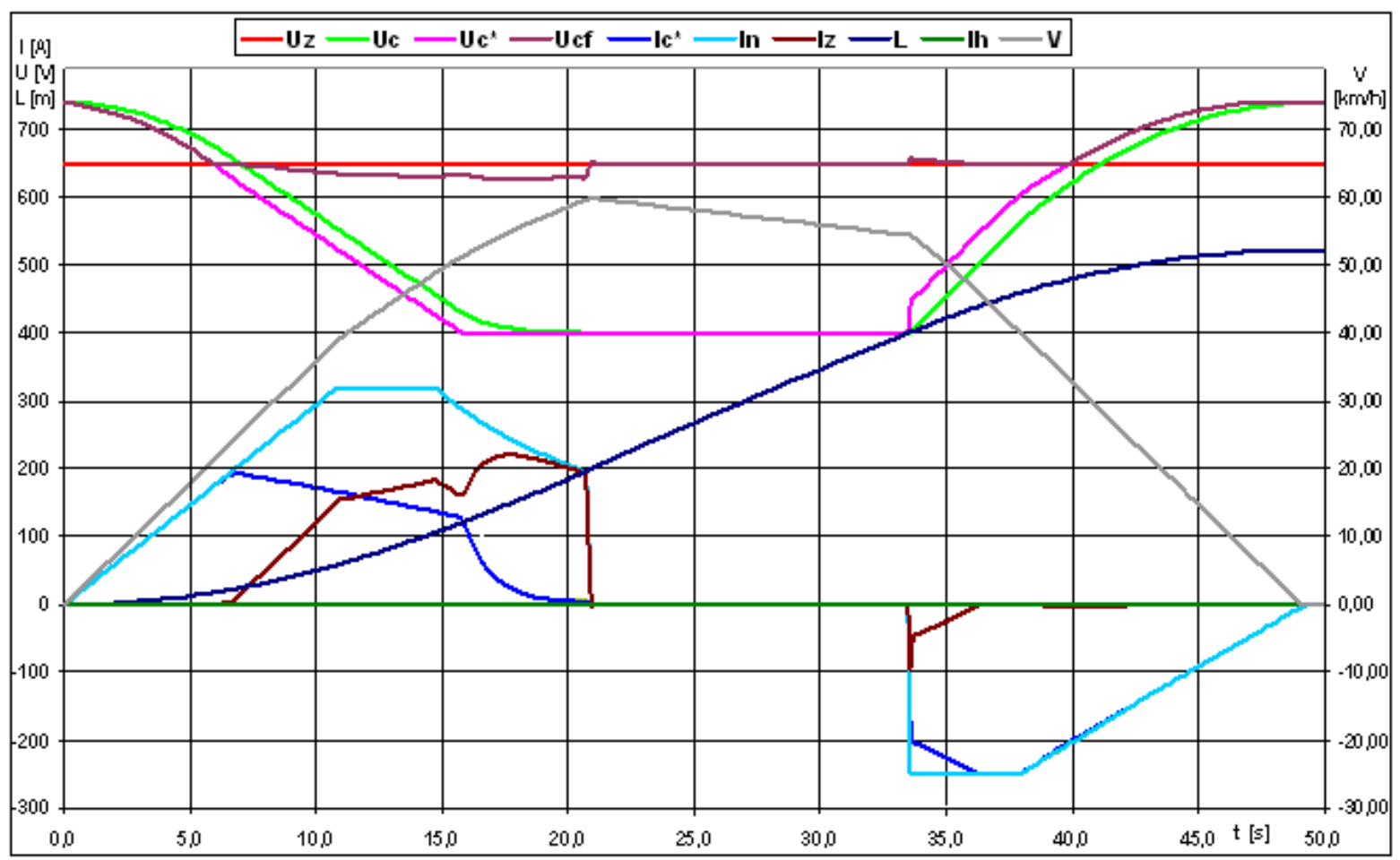




\section{Badania ruchowe i eksploatacyjne zrealizo- wanych układów}

\subsection{Trolejbusy}

Dla Kowna dla trolejbusu Jelcz M121 z napędem silnikiem $\mathrm{DC}=120 \mathrm{~kW}$ wykonano i dostarczono zasobnik 8,9F-780V wraz z układem regulacyjnym.

Dla MPK Lublin wykonano i zbadano trolejbus Jelcz PR110 z zasobnikiem napędzanym silnikiem AC165kW kondensatorowym 8,9F-780V oraz dodatkowo $\mathrm{z}$ zasobnikiem akumulatorowym ok $6 \mathrm{kWh}$ umożliwiającym przejazd odcinka $2 \div 3 \mathrm{~km}$ bez zasilania z sieci trakcyjnej.

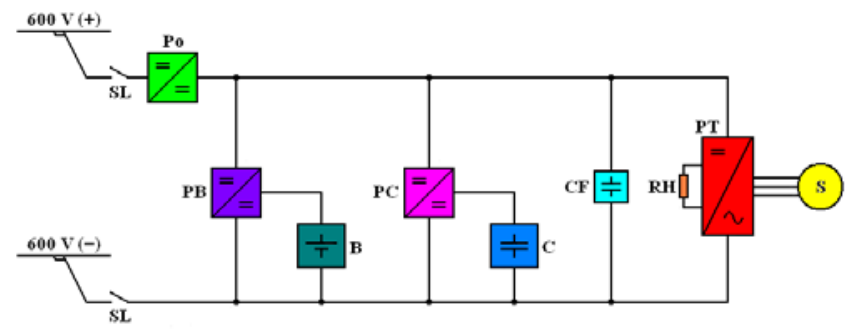

Oznaczenia:

$\begin{array}{ll}\text { SL } & \text { Styczniki liniowe } \\ \text { PT } & \text { Przekształtnik trakcyjny DC/DC (lub falownik) } \\ \text { S } & \text { Silnik trakcyjny prqdu statego DC (lub asynchroniczny } \\ & \text { AC) } \\ \text { RH } & \text { Opornik hamowania } \\ \text { CF } & \text { Kondensator filtru } \\ \text { Po } & \text { Przekształtnik odzysku energii do sieci trakcyjnej } \\ \text { PC } & \text { Przekształtnik zasobnika kondensatorowego } \\ C & \text { Zasobnik kondensatorowy } \\ \text { PB } & \text { Przekształtnik zasobnika akumulatorowego } \\ B & \text { Zasobnik akumulatorowy }\end{array}$

Rys.3 Schemat blokowy obwodu głównego z zasobnikami kondensatorowym i akumulatorowym
(Dla Autrolis Kowno schemat jest podobny tylko bez baterii akumulatorów)

Przykładowe przebiegi wielkości elektrycznych pokazane są na rys 4-6

Badania ruchowe i eksploatacyjne trolejbusów z kondensatorowym zasobnikiem energii $8.9 \mathrm{~F}, 780 \mathrm{~V}$ wykonano:

a) W Lublinie $\mathrm{z}$ falownikowym układem napędowym o mocy silnika $165 \mathrm{~kW}$ w okresie czerwiec - październik 2007 roku. Trolejbus podczas prób obciążony był dodatkową masą $8 \mathrm{Mg}$. W MPK wykonano również badania $\mathrm{z}$ dodatkowym akumulatorowym zasobnikiem energii.

b) W Kownie z przekształtnikowym (DC/DC) układem regulacyjnym o mocy silnika $120 \mathrm{KW}$ w okresie lipiec - wrzesień 2008 roku i przekazano trolejbus do normalnej eksploatacji.

Przykładowe przebiegi napięć i prądów dla jazdy trolejbusu z zasobnikiem kondensatorowym pokazane są na oscylogramach $1 \div 3$.

Oscylogram osc. 1 przedstawia przebiegi dla jazdy bez kondensatorowego zasobnika energii. Maksymalna prędkość trolejbusu wynosiła ok. $50 \mathrm{~km} / \mathrm{h}$. Średnia wartość prądu silnika (IS) podczas rozruchu wynosi ok. 345A. Prąd pobierany z sieci trakcyjnej (IZ) narasta liniowo i osiaga wartość ok. 350A przy prędkości ok. $36 \mathrm{~km} / \mathrm{h}$. Energia pobrana $\mathrm{z}$ sieci trakcyjnej podczas rozruchu wynosi ok. $0,2 \mathrm{kWh}$, a dla jazdy do $\mathrm{V}=45 \mathrm{~km} / \mathrm{h}$ wynosi ok. $0,3 \mathrm{kWh}$. Podczas hamowania energia kinetyczna trolejbusu wytracana była w opornicy hamowania.

Osc.1 Przejazd trolejbusu zasilanego z sieci trakcyjnej bez zasobnika kondensatorowego

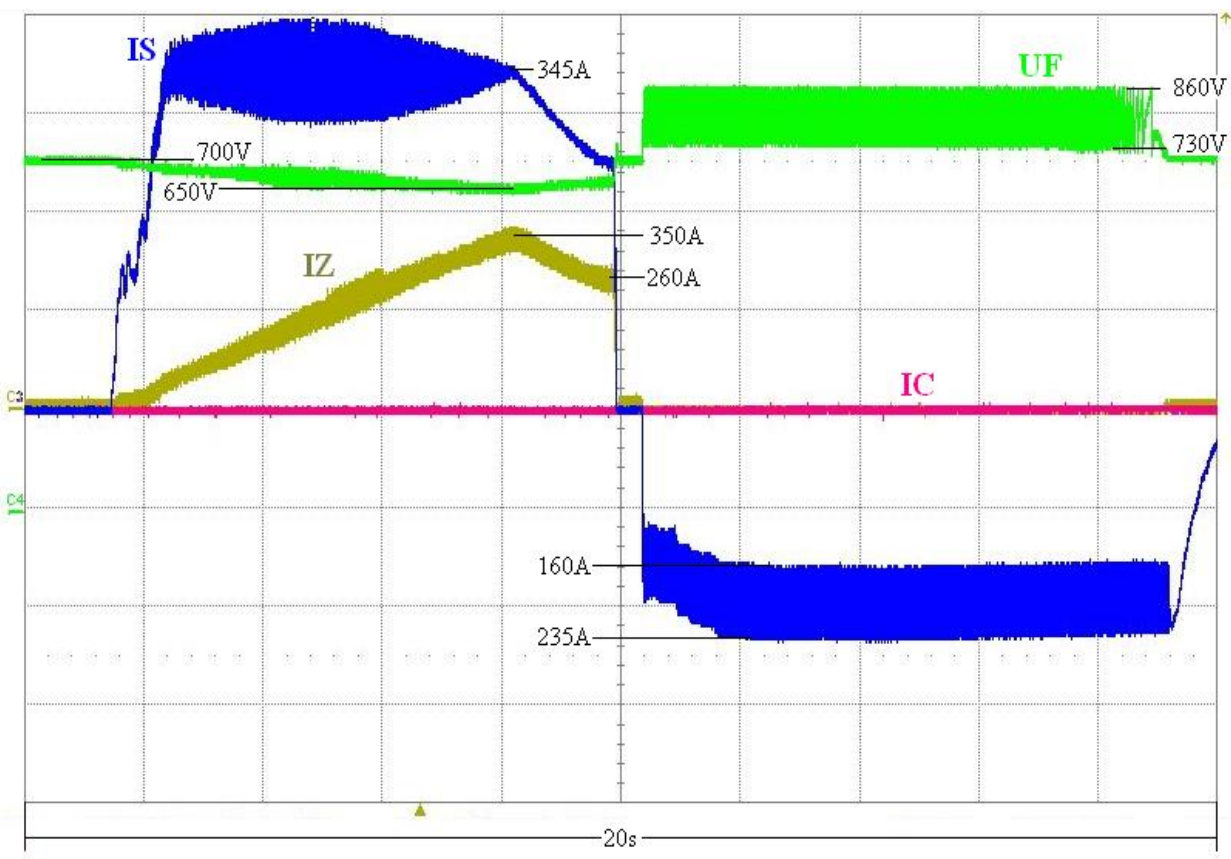

Legenda:

IS - prąd silnika,

IC-prąd zasobnika kondensatorowego, $I Z$ - prad sieci trakcyjinej,

$U F$ - napiecie kondensatora filtru wejściowego przeksztaltnika DC/DC 


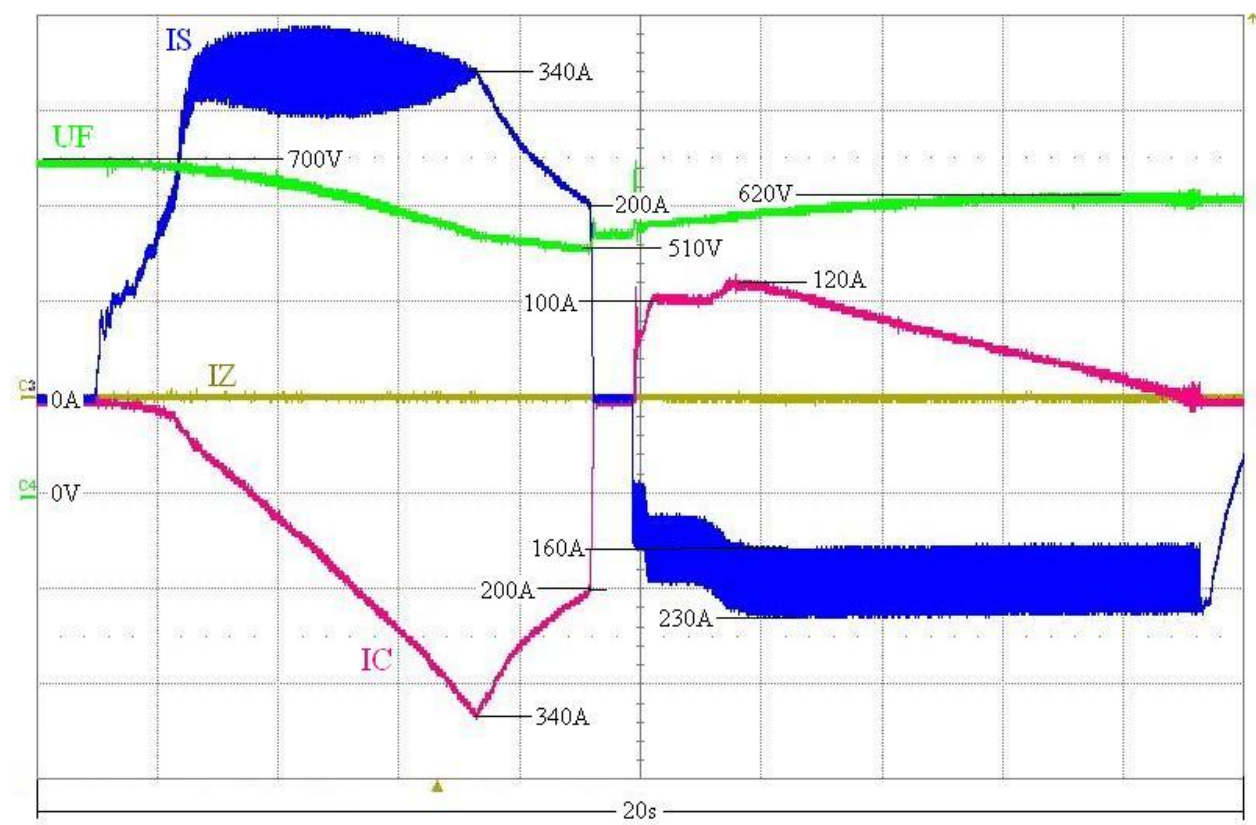

Osc.2 Przejazd trolejbusu bez sieci zasilanego $\mathrm{z}$ zasobnika kondensatorowego

\section{Legenda: \\ IS - prq̨d silnika, \\ IC-prąd zasobnika kondensatorowego, IZ - prad sieci trakcyjnej, UF - napiecie kondensatora filtru wejściowego przeksztaltnika DC/DC}

Oscylogram osc. 2 przedstawia przebiegi prądów i napięć podczas jazdy bez zasilania z sieci trakcyjnej na ulicy w Kownie. Początkowa wartość napięcia zasobnika kondensatorowego wynosi $700 \mathrm{~V}$. Podczas rozruchu z prądem silnika $\sim 340 \mathrm{~A}$ kondensator rozładowuje się do ok. 550V, a przy dalszej jeździe do 510V. Maksymalna wartość prądu pobranego z kondensatora wynosi 340A. Energia pobrana z kondensatora wynosi $\sim 0.26 \mathrm{kWh}$. Podczas hamowania zasobnik kondensatorowy został doładowany do wartości napięcia ok. 620V. Energia zwrócona podczas hamowania wynosi $\sim 0.14 \mathrm{kWh}$

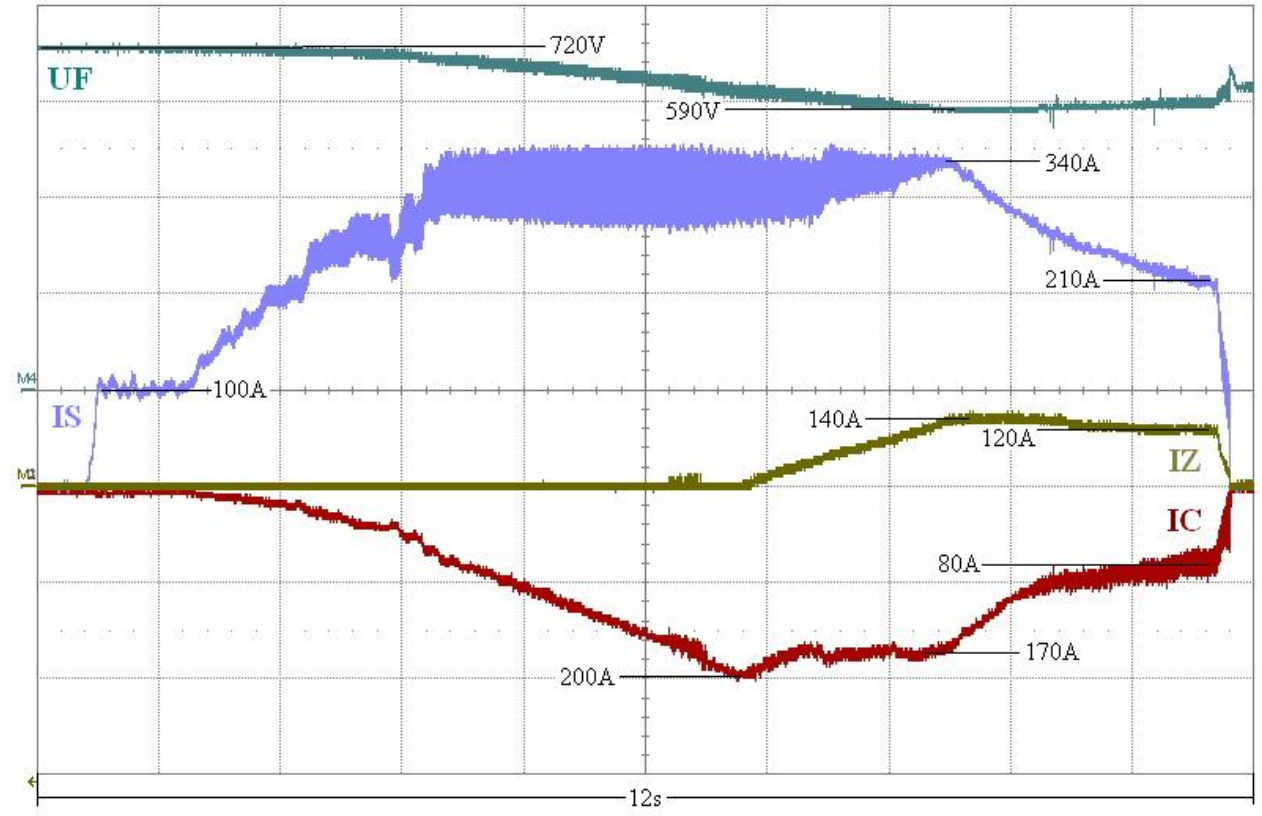

Osc.3 Przejazd trolejbusu zasilanego z sieci trakcyjnej i zasobnika kondensatorowego

\section{Legenda:}

IS - prąd silnika,

IC-prąd zasobnika kondensatorowego, IZ - prad sieci trakcyjnej,

$U F$ - napięcie kondensatora filtru wejściowego przeksztaltnika DC/DC

\section{Wnioski:}

Badania ruchowe i eksploatacyjne trolejbusów z napędem falownikowym zasilającym silnik asynchroniczny AC o mocy $165 \mathrm{~kW}$ oraz przekształtnikowym zasilającym silnik prądu stałego DC o mocy $120 \mathrm{~kW}$ wykazały prawidłową pracę $\mathrm{i}$ regulację kondensatorowego układu zasilania napędu współpracującego z siecią trakcyjną.

a) Podczas jazdy trolejbusu nieobciążonego $(12 \mathrm{Mg})$, przy zasilaniu z sieci trakcyjnej i zasobnika kondensatorowego (osc.3) następuje:
- zmniejszenie wartości maksymalnej prądu pobieranego z sieci trakcyjnej z $340 \mathrm{~A}$ do ok. 140A;

- dla rozpędzenia trolejbusu (pustego) do prędkości $\sim 45 \mathrm{~km} / \mathrm{h}$, przy wyższym napięciu zasobnika od napięcia sieci, ok. $70 \%$ energii (potrzebnej na napęd) pobranej jest $\mathrm{z}$ zasobnika kondensatorowego, a zaledwie $30 \% \mathrm{z}$ sieci trakcyjnej; 
- w przypadku trolejbusu obciążonego udział energii pobranej z sieci trakcyjnej wzrośnie, a także zwiększy się wartość maksymalnego prądu pobranego $\mathrm{z}$ sieci trakcyjnej.

a) Podczas jazdy trolejbusu obciążonego masa pasażerów $(12+8 \mathrm{Mg})$, przy wartości napięcia sieci $\sim 600 \mathrm{~V}, \mathrm{z}$ prądem rozruchu $\sim 320 \mathrm{~A}$ :

- maksymalna wartość prądu pobranego z sieci trakcyjnej (przy $\mathrm{V} \geq 30 \mathrm{~km} / \mathrm{h}$ ) wynosi ok. 260A;

- maksymalna wartość prądu pobranego z zasobnika kondensatorowego wynosi ok. $125 \mathrm{~A}$;

- zmniejszenie wartości maksymalnej prądu pobranego $\mathrm{z}$ sieci $\mathrm{z}$ ok. $330 \mathrm{~A}$ do ok. 260A.

b) Podczas badań w Kownie trolejbusu znajdującego się w normalnej eksploatacji (ze zmiennym obciążeniem, profilem trasy, sposobem jazdy i wartością napięcia sieci) uzyskano następujące wyniki:

- stosunek poboru energii z sieci trakcyjnej do energii pobranej przez napęd i obwody pomocnicze $\sim 0,68$;

- stosunek poboru energii $\mathrm{z}$ zasobnika kondensatorowego do energii pobranej przez napęd i obwody pomocnicze $\sim 0,32$;

- stosunek energii zwróconej do zasobnika kondensatorowego do energii pobranej $\mathrm{z}$ sieci trakcyjnej $\sim 0,35$.

c) Zastosowanie kondensatorowych zasobników energii umożliwia więc uzyskanie w normalnej eksploatacji oszczędności energii $30 \div 35 \%$, czyli zgodnie $\mathrm{z}$ przyjętymi założeniami.

d) Trolejbus $\mathrm{z}$ zasobnikiem energii $\sim 9 \mathrm{~F}$ może przejechać bez zasilania z sieci trakcyjnej, z opuszczonymi odbierakami prądu odcinek ok. $200 \div 300 \mathrm{~m}$ (osc.2). Umożliwia to, w przypadku awarii, objazd uszkodzonego odcinka sieci trakcyjnej, a także jazdy po zajezdni podczas manewrów bez konieczności podłączania odbieraków do sieci.

\subsection{Tramwaj 116N}

Napęd tramwaju stanowią silniki 50kW $300 \mathrm{~V}$ połączone po dwa silniki w grupie. Zastosowano zasobnik kondensatora $10 \mathrm{~F}-760 \mathrm{~V}$ f-my $\mathrm{LS}$ Mtron. w punkcie 4 .

Działanie układu podobne z przedstawionym

Uzyskane podczas badań ruchowych przebiegi wielkości elektrycznych podczas rozruchu i hamowania pokazane są na rys $5 \div 10$.

Rysunek 5 i 6 przedstawia przebieg dla rozruchu i hamowania bez wspomagania z zasobnika kondensatorowego.

Rys.4 Schemat układu napędowego tramwaju 116N

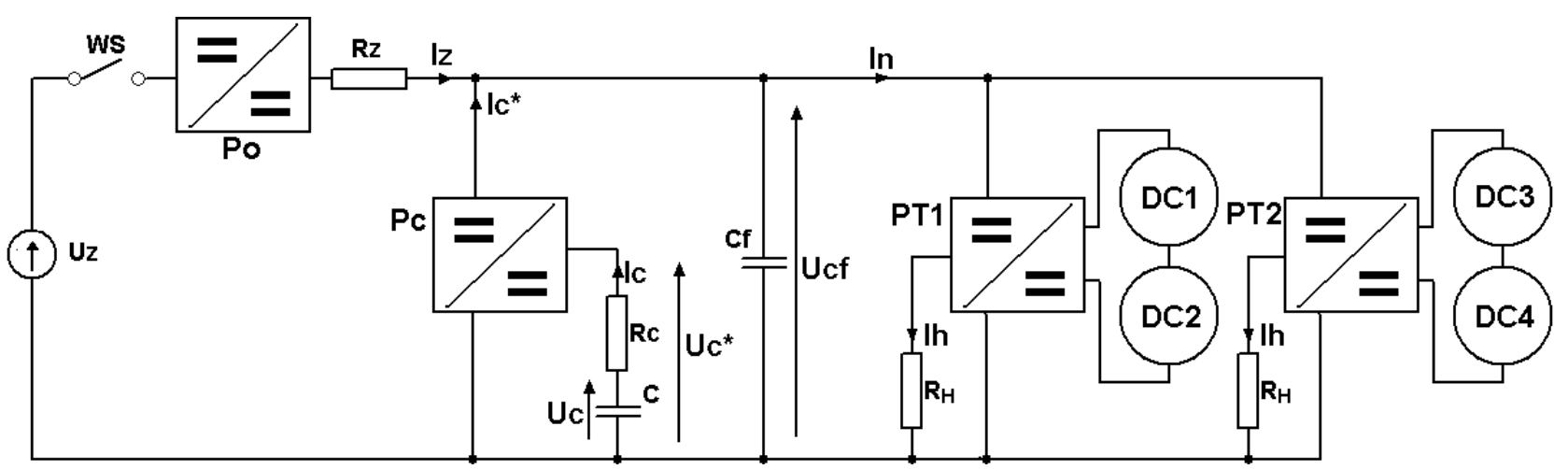




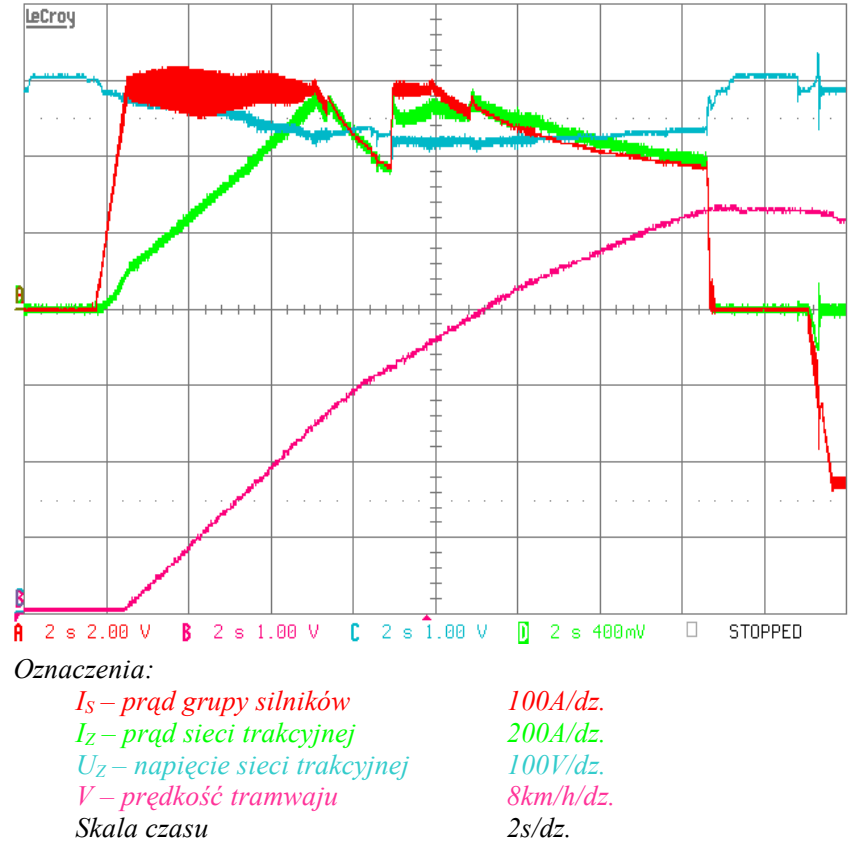

Rys. 5 Rozruch do ok. $44 \mathrm{~km} / \mathrm{h}, \mathrm{U}_{\mathrm{Z}}=710 \mathrm{~V}, \mathrm{I}_{\mathrm{S}}=2 \mathrm{x} 290 \mathrm{~A}$

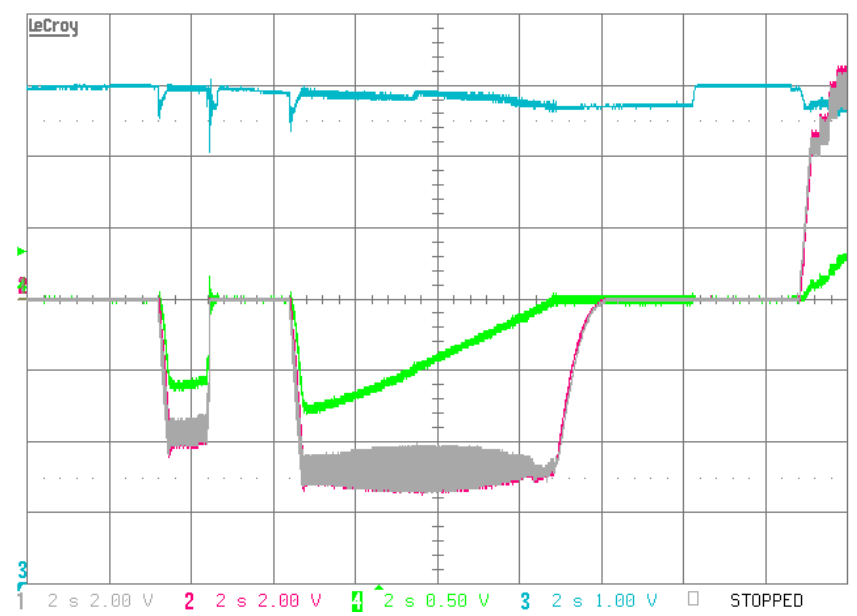

Oznaczenia:
$I_{S I}-$ prad I grupy silników
$I_{S 2}$ - prad II grupy silników
$I_{Z}$ - prad sieci trakcyjnej
$U_{z}$ - napiecie sieci trakcyinej
Skala czasu

$$
\begin{aligned}
& 100 \mathrm{~A} / \mathrm{dz} . \\
& 100 \mathrm{~A} / \mathrm{dz} . \\
& 250 \mathrm{~A} / \mathrm{dz} . \\
& 100 \mathrm{~V} / \mathrm{dz} .
\end{aligned}
$$
$2 s / d z$.

Rys. 6 Hamowanie $\mathrm{z} V=35 \mathrm{~km} / \mathrm{h}, \mathrm{U}_{\mathrm{Z}}=700 \mathrm{~V}, \mathrm{I}_{\mathrm{S}}=2 \times 230 \mathrm{~A}$

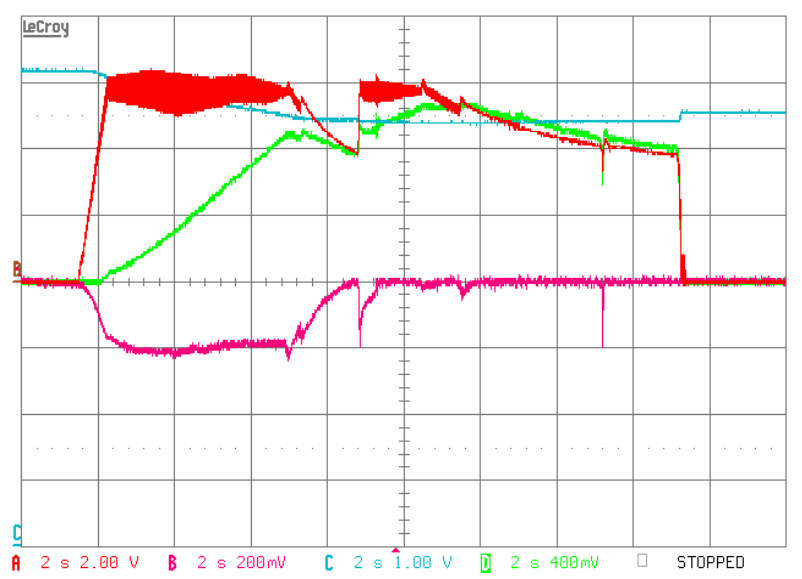

Oznaczenia
$I_{S}$ - prad grupy silników
$100 \mathrm{~A} / \mathrm{dz}$
$I_{Z}$ - prad sieci trakcyjnej
$I_{C}$ - prad zasobnika
$100 A / d z$
$U_{Z}$ - napiecie zasobnika
$100 \mathrm{~V} / \mathrm{dz}$
Skala czasu
$2 s / d z$.

Rys.7 Rozruch tramwaju

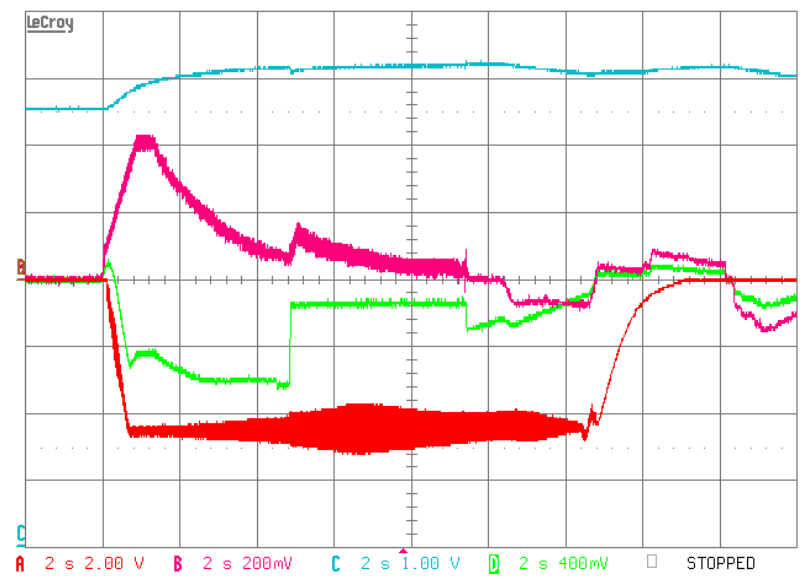

Oznaczenia:

$\begin{array}{ll}I_{S}-\text { prad grupy silników } & 100 \mathrm{~A} / \mathrm{dz} . \\ I_{Z}-\text { prad sieci trakcyjnej } & 100 \mathrm{~A} / \mathrm{dz} . \\ I_{C}-\text { prad zasobnika } & 100 \mathrm{~A} / \mathrm{dz} . \\ U_{Z}-\text { napięcie zasobnika } & 100 \mathrm{~V} / \mathrm{dz} . \\ \text { Skala czasu } & 2 \mathrm{~s} / \mathrm{dz} .\end{array}$

Rys.8 Hamowanie tramwaju

Rysunek 7 i 8 przedstawia podobne przebiegi przy bezpośrednim włączeniu zasobnika kondensatorowego

Rysunek 9 i 10 przedstawia przebiegi przy regulacji pracy zasobnika wg patentu IEL.

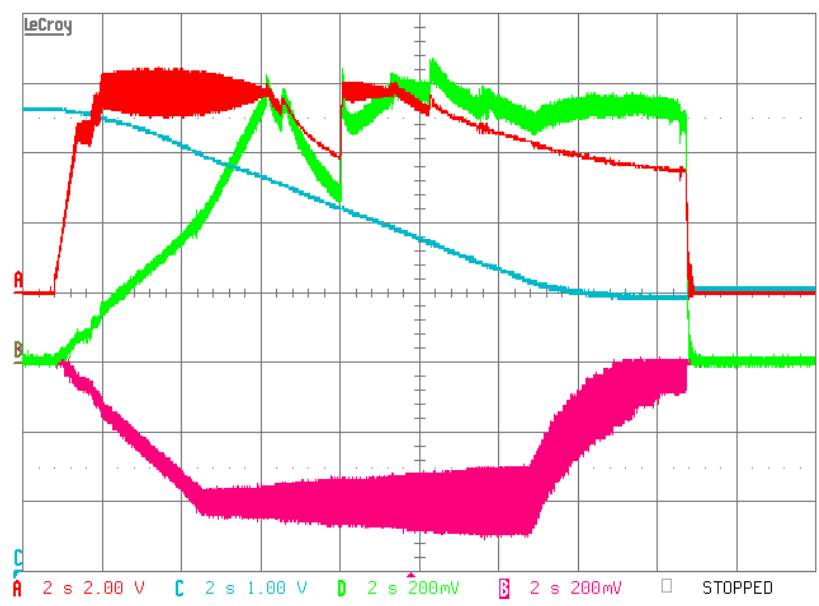

Oznaczenia:
$I_{S}$ - prad grupy silników
$100 \mathrm{~A} / \mathrm{dz}$.
$I_{z}$ - prad sieci trakcyjne
$100 \mathrm{~A} / \mathrm{dz}$
$I_{C}$ - prad zasobnika
$100 \mathrm{~A} / \mathrm{dz}$
Uz-napiecie zasobnita
$100 \mathrm{~V} / \mathrm{dz}$
Skala czasu
$2 s / d z$.

Rys.9 Rozruch tramwaju $\mathrm{I}_{\mathrm{S}}=290 \mathrm{~A}, \mathrm{U}_{\mathrm{Z}}=650 \mathrm{~V}, \mathrm{U}_{\mathrm{Co}}=670 \mathrm{~V}$ 


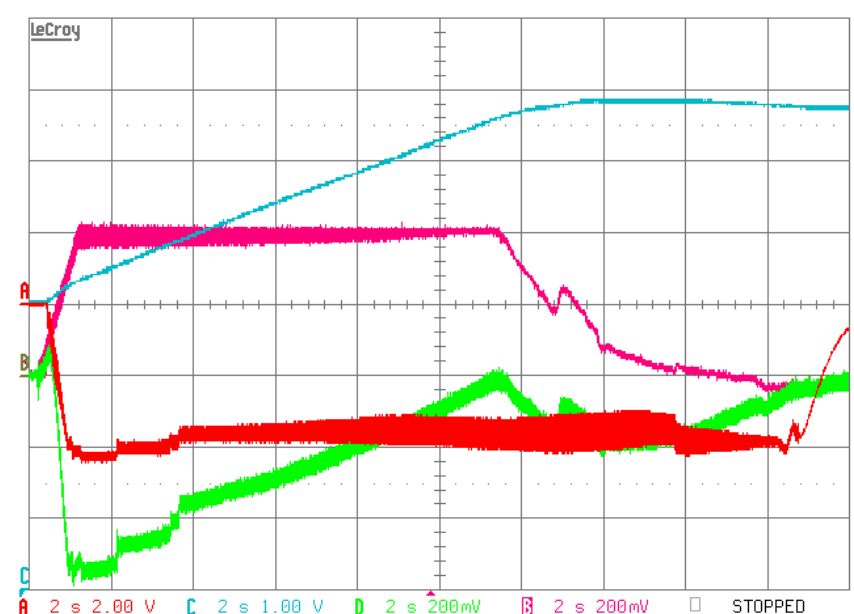

Oznaczenia

$\begin{array}{ll}I_{S} \text { - prad grupy silników } & 100 \mathrm{~A} / \mathrm{dz} . \\ I_{Z} \text {-prad sieci trakcyjnej } & 100 \mathrm{~A} / \mathrm{dz} . \\ I_{C}-\text { prad zasobnika } & 100 \mathrm{~A} / \mathrm{dz} . \\ U_{Z}-\text { napięcie zasobnika } & 100 \mathrm{~V} / \mathrm{dz} . \\ \text { Skala czasu } & 2 \mathrm{~s} / \mathrm{dz} .\end{array}$

Rys.10 Hamowanie tramwaju $\mathrm{I}_{\mathrm{S}}=200 \mathrm{~A}, \mathrm{U}_{\mathrm{Z}}=650 \mathrm{~V}, \mathrm{U}_{\mathrm{Co}}=400 \mathrm{~V}$

\section{Wnioski z badań}

1. Bezpośrednie włączenie zasobników kondensatorowych w układ napędowy tramwajów nieznacznie tylko obniża maksymalną wartość prądu sieci i przyjmuje tylko ok. 10\% energii zwracanej przez tramwaj.

2. Zastosowany w pojazdach układ regulacyjny (wg patentu IEL) umożliwia:

- ograniczenie do ok. $60 \%$ maksymalna wartość prądu pobranego z sieci trakcyjnej w stosunku do maksymalnej wartości prądu pobieranego przez napęd podczas rozruchu

- zasobnik dostarcza ok. 30\% energii pobranej przez napęd, podczas hamowania z prędkości ok. $50 \mathrm{~km} / \mathrm{h}$ zasobnik przejmuje ok $50 \%$ energii zwracanej przez silnik.

\section{Wnioski:}

1. Wykonane badania symulacyjne i eksploatacyjne pojazdów z zasobnikowymi układami wspomagającymi rozruch i akumulującym energię hamowania wykazały w pełni zasadność techniczną stosowania takich układów w pojazdach komunikacji miejskiej.

2. Opracowane układy z systemem regulacji wg patentu IEL skutecznie obniżają maksymalną wartość prądu sieci podczas rozruchu zmniejszając o $50 \%$ straty w sieci zasilającej i umożliwiają akumulację całej energii zwracanej przez silnik podczas hamowania pojazdu.

3. W tramwaju $116 \mathrm{~N}$ uzyskano zmniejszenie zużycia energii ok $0,9 \mathrm{kWh} / \mathrm{km}$ co przy rocznym przebiegu tramwaju 50tyś km daje oszczędność ok 45 MWh (ok 15 tyś zł) nie licząc zmniejszenia kosztów pobieranych przez energetykę

4. Koszt układu zasobnikowego $10 \mathrm{~F}-760 \mathrm{~V}$ wraz z przekształtnikowym układem regulacyjnym można oszacować na $120 \div 140$ tyś zł $\mathrm{w}$ tym koszt kondensatora wynosi ok $80 \div 90$ tyś zł. Zwrot nakładów nastąpi po ok $7 \div 8$ latach

Deklarowana żywotność kondensatorów wynosi ponad milion cykli w zakresie Un-0,5Un czyli przy dwóch rozruchach na $1 \mathrm{~km}$ trwałość wyniesie ponad 10 lat. 